\title{
SPACES OF DISAGREEMENT
}

The text asks how dissent can be organized spatially. Although, taking recent developments in arts, architecture and urban planning into consideration, the focus is put on two projects of the artist and architect Apolonija Šušteršič: the café KAFIČ, commissioned by Galerie für Zeitgenössische Kunst Leipzig, and the Community Pavilion in Hustadt, commissioned by the municipality of Bochum. Following these examples the text discusses the possibilities of how to transmute social antagonism into agonism thereby creating a vibrant public sphere that allows the expression of competing notions, opinions and approaches.

DISSENT

CONFLICT

DISAGREEMENT

PUBLIC

SPACE

ANTAGONISM

AGONISM 
At the most general of levels, architecture and urban planning seek to organize space.

However, what if there is no consent how to do that? This is increasingly the case when it comes to public spaces. What if authoritarian planning able to repress conflicts of interests - is not legitimate any longer? What if, municipal authorities, planning committees, entrepreneurs, housing associations and residents are neither able to come to an agreement with one another nor within the groups themselves? For some years now - aside from architects and urban planners - artists have been invited to find solutions for participation and inclusion. Ironically, they are quite often asked by architects and urban planners to join them. It might also be fair to say that in this regard art is overloaded with expectations. Artists are rightly critical of this. The artist, Kristina Leko, for instance, clearly does not accept the idea that art can solve problems or compensate for societal deficiencies and relieve politics of its responsibilities. In her view 'art cannot replace urban planning or other social disciplines'. Leko is interested far more in the social potential of art itself, which she believes has the capacity to "generate changes in relationships and perceptions."

However, the expectation that art might compensate for societal deficiencies, specifically the disintegration of public life, has not merely emerged in recent years. This notion was already aired in 1973 at the Deutscher Städtetag in Bremen and featured in an aspirational paper on 'art in public spaces'. In view of the ongoing debate concerning the disintegration of public life and urban living spaces, pedagogical and socio-political demands were now being imposed on art, which was to stimulate communication, combat isolation, create new room for manoeuvre and act as a counter-balance to the constraints imposed by the constraints of daily life. ${ }^{2}$ Apart from the fact that art is regarded here as an instrument of sorts, all these demands are based on the same concept of public life: ideally it is conceived by equals as a sphere for equals. But what if this ideal entity no longer exists? What if different socialisations have formed regardless of topographical considerations and exist in parallel to each other, if an 'entity' is not even imaginable any more?

To discuss these issues profoundly I would like to take up one example: the work of the artist and architect Apolonija Šušteršič. Concretely I would like to present two projects, one she did for Leipzig and one for Bochum, both in Germany. ${ }^{3}$ 
In 2009 Apolonija Šušteršič and Meike Schalk accepted my invitation to redesign the café at the Stiftung Galerie für Zeitgenössische Kunst (GfZK) in Leipzig. The new KAFIC - the name that was ultimately chosen for the refurbished café - was to be a place that not only expressed diverse cultural experiences but where different cultures could meet, creating and sharing space with each other. This idea was similar to that of Hustadt in Bochum. There was also a similarity in the fact that the café would owe its existence to so many parties besides the GfZK - the authorities, various associations, municipal partnerships and numerous volunteers. Šušteršič and Schalk made a particular point of working with groups who are not normally especially visible and who have little or no space of their own in public life. These groups were to be explicitly given space; besides being invited to contribute to the refurbishment of the café they were to make this space their own and use it as a meeting place. Ultimately - again like the Hustadt project - KAFIČ has taken some time to realize. Over the course of two years a series of workshops took place, on topics including the basics of furniture construction and how to work with textiles, which have seen the two artists making a series of visits to Leipzig. Strictly speaking the café is still not finished - it is still constantly changing even although it is already in business.

There is, however, a fundamental difference between Leipzig and Hustadt in the commissioning client: in Bochum it was a municipal authority, in Leipzig it is a contemporary art institution. Moreover the publicly funded project in Bochum was much more exposed and the financial implications that much greater. This was an urban development project, for which an artist was invited to take up a residency and to become involved in the redesign of the Brunnenplatz in Hustadt. For some decades now this part of Bochum has been undergoing a process of immense transformation. Over the years it has moved on from the initially utopian aspirations of its beginnings in the 1960s and has progressed towards what might be described as a lived reality of different life models. Today this part of Bochum has a culturally mixed populace with very different ideas on social co-existence. In addition to this there are the many assumptions, classifications and notions presented in the press and media on what it means to live in Hustadt or to administer this 'city in a city'. Hustadt is a highly complex web of connections and vested interests, of political, economic, social and artistic aims; there are the needs of its residents, who value low living costs and informal networks, and the aspirations of its local political leaders, who are determined to raise the standard of living and to increase the appeal of this district as a whole for 'not-already-Hustadters'. As yet, in Hustadt there is no viable public space where, despite the diversity of 
origins and views, residents can come together to discuss common concerns, a space that is equally open to all, that individuals can identify with.

That was the situation Šušteršič found when she embarked on her project in Hustadt; her project there had to contend with different - one might also say, competing - interests and forces to those of the café project in Leipzig. For one thing is true of all art projects in public spaces: they are open to criticism, they are exposed - much more than in the protected realms of an art institution. Different codes apply, different modes of perception and a different willingness to engage, or rather not to engage with an art project. Art in public spaces is more controversial and sometimes even literally destroyed. At times it is used as a political football, more often it is just ignored.

There is also the fact that with time notions of both art and public spaces have radically changed. Although we might applaud the fact that people have a more differentiated understanding of art in public spaces, the overall situation has not become easier, because this also means that expectations of art in public spaces have been raised. In other words, art that is appreciated for its own sake, regardless of its surroundings, has now been joined by site-specific art, art-in the-public-interest and new-genre-public art. ${ }^{4}$ The demonstrative lack of connection between work and surroundings was met in the 1960s and 70s with the new demands of site specificity, whereby the particularities of a place, its situation, its history and its function all played into the artistic concept. Increasingly municipal authorities, planning committees, entrepreneurs and housing associations involved artists in the design of public and semi-public spaces, in the hope that the urban experience in their city would be enhanced by art, in order to foster positive identification and public life. In the 1980s the potential of art in public spaces was often reduced to financially beneficial image and location factors. For some years now, be it in the East or the West, in Germany or elsewhere, artists have been invited to actively engage with social transformation and with the places affected by change, to come up with proposals for new uses and changes of use, and/or to stimulate participation and a sense of community. The expectations of art in these circumstances are immense; in the best case scenario these days artistic, socio-cultural and political aspects come together, public life is enhanced, value is added and a particular image policy is pursued. Interestingly, at various times each of these aspects individually has dominated the discourse and counter-discourse on art in public spaces: in the 1970s the focus was on public life per se, in the 1980s it was - at least in the West - on image politics and in the 1990s it was on selfempowerment. Today there is a drive to combine all of these aspects. 
In her Hustadt project Apolonija Šušteršič addresses people and groups with widely diverse ideas and attitudes: people with very different roots, with assorted cultural backgrounds - students, children, young people, adults and old people, some who have just moved to the area, others who have lived here for many years. Šušteršič's project is notable for the fact that from the outset she took a de facto divergent space as her starting point and set out to investigate existing (antagonistic) spaces in terms of their potential for a coming together in diversity. These antagonistic spaces are political, economic, social and cultural (which these days also crucially includes the media) in nature; they interconnect and overlap, they attract each other, they repel each other and come into conflict. Within and by means of her project Šušteršič creates a conceptual, substantive and spatial framework that allows individuals (perhaps for the first time) to reconsider their own attitudes in light of other attitudes, to articulate different approaches and to seek out common ground - however temporary that might be. The creation of frameworks that make this form of encounter possible was of course not achieved merely by constructing the pavilion that, shortly before its opening, was suddenly the focus of media and political attention; for this was the culmination of a lengthy process that started in 2008 and continued until and beyond the inauguration of the big pavilion - the Community Pavilion. Material and immaterial factors are equally important in this project: these include numerous formal and informal meetings with Hustadt residents, workshops, discussions, but also the mobile-phone-camera project with students, the children's planting action, the temporary pavilion, the café and now the big pavilion with its summer kitchen, its welcome areas, stage and open-air cinema. 'Beyond' the day of the official opening also means that the project is set up in such a way that it can accommodate change - while certain functions may come to an end, new ones will come to replace them.

At this point it is perhaps worth mentioning that Šušteršič is also a trained architect. Her approach in this project has been thoroughly 'architectural'. She has designed a space, but a space that is not static - it is fluid and arises from and is altered by countless actions and movements involving numerous individuals. This intrinsically differentiated, multiple space that is fundamentally grounded in Henri Lefèbvre's concept of space, ${ }^{5}$ forms the basis of Šušteršič's approach. In her project for Hustadt her aim has been to create a sense of public life in this socially differentiated, multiple space, which allows individuals to negotiate possible shared issues without having to deny differences.

Šušteršič's efforts to 'create a public space' of course have to be, in the best sense, somewhat utopian. Fundamentally, her Community Pavilion and 
various related activities constitute a statement - a possible, contemplatable or imaginable version of community and public life. In so doing she highlights the imaginative potential of utopias - as alternatives to the status quo and as an inspiration to create societal spaces with emancipatory energy. Interestingly, it seems these days that not only has utopian thinking very much been pushed into the background, we have also witnessed the demise of various projects designed to promote the partnership of all social groups in political, economic and cultural life. Perhaps one way of reading Šušteršič's work is to see her concrete actions, her activities and projects, as a way of allowing a utopia to momentarily loom into sight and of airing the possibility of communityoriented attitudes and behaviour in an increasingly diverse society.

For the project in Hustadt is and will always be tied to the reality of this part of Bochum. People and groups are addressed here whose attitudes and views are by definition polarised. Competing notions, opinions and approaches come together and go head to head; they clash and can lead to conflict. Šušteršič's project has created a framework that makes it possible not only to reflect these but also to transmute social antagonisms into agonies. This in turn, to cite Chantal Mouffe, leads to 'a vibrant agonistic public sphere' in which different attitudes can be confronted with each other and conflicts are given 'a legitimate form of expression'. ${ }^{6}$ And this in turn provides the conditions where individuals can discuss differences and potential common ground, where communities might just stand a chance of forming. In practical terms the situation is not always pleasant, as was already apparent at the opening celebrations for the Community Pavilion. The celebrations began with a programme presented by various groups from Hustadt - from a women's choir to a rapper. Šušteršič organised the evening programme, to which she had invited other artists and myself as speaker. But this second part of the opening celebrations was initially drowned out by children, young people and adults who wanted to play, dance and sing, and who neither had any interest in Šušteršič's programme nor felt like handing over 'their' stage to a small group of art enthusiasts. You could say that this was the litmus test for Šušteršič's project: after an intermediate period of mutual persuasion and intense competition for temporary performers' rights Šušteršič's programme went ahead one hour later than planned. Ultimately a number of Hustadters even joined the audience. I even gave my lecture - no matter that I had to shout for the first ten minutes, just to make myself heard. 
Kristina Leko, "Gesellschaftliche Veränderungen, Selbstermächtigung und Imagination," in: Schrumpfende Städte, vol. 2, Handlungskonzepte, ed. Philipp Oswalt. (Ostfildern/Ruit: Cantz, 2005). p. 501.

On this, see also Claudia Büttner: Art goes public. (München: Schreiber, 1997). p.137.

This text is based on two lectures I did on invitation of Apolonija Šušteršič, one about the KAFI $\check{C}$ at the GfZK in Leipzig in 2010, and the other one about her Community Pavilion in Hustadt, Bochum, 2011. The latter was held on the occasion of the inauguration of the pavilion. An amended version of this lecture was published for Artes Mundi, Wales. See above all Miwon Kwon on site specifity: Miwon Kwon, One Place after Another: Site Specific Art and Locational Identity. (Cambridge/ London: MIT Press, 2002). 
Miwon Kwon, One Place after Another: Site Specific Art and Locational Identity. Cambridge/ London: MIT Press, 2002

Henri Lefèbvre, The Production of Space. trans. Donald Nicholson-Smith, Oxford: Basil Blackwell,1991

Kristina Leko, "Gesellschaftliche Veränderungen, Selbstermächtigung und Imagination", in: Schrumpfende Städte, vol. 2, Handlungskonzepte, ed. Philipp Oswalt, Ostfildern/Ruit: Cantz, 2005

Chantal Mouffe, On the Political. Abingdon and New York: Routledge, 2005

Barbara Steiner, „Apolonia Šušteršič, Agonising for Community. A Practical Text in Hustadt”, in: artes mundi, Exhibition Catalogue. Cardiff: Artes Mundi Prize Limited, 2012 


\section{PROSTORI RAMIMOILAŽENJA}

\section{Barbara Steiner}

Ovaj tekst postavlja pitanje kako neslaganje može prostorno da se organizuje. Premda, uzimajući nedavne razvoje u umetnosti, arhitekturi i urbanom planiranju u razmatranje, $u$ fokusu su dva projekta umetnice i arhitekte Apolonije Šuštrešič: kafe KAFIČ, koji je naručila Galerie für Zeitgenössische Kunst Leipzig i (Community Pavillion) Paviljon zajednice u Hustadtu, koji je naručila opština Bochum. Prateći ova dva primera ovaj tekst razmatra mogućnosti kako da se društveni antagonizam preobrazi u agonizam time kreirajući živahnu javnu sferu koja dozvoljava izražavanje takmičarskih pojmova, mišljenja i prilaza.

KLJUČNE REČI: NESLAGANJE, KONFLIKT, RAZILAŽENJE, JAVNI PROTSOR, ANTAGONIZAM, AGONIZAM

POJAM I ZNAČENJE MEĐUDISCIPLINARNOSTI

U PROUČAVANJU UMETNOSTI I MEDIJUMA

\section{Nikola Dedić}

Ovaj tekst pokušava da označi razliku između tradicionalnih, modernih monodisciplinarnih i savremenih međudisciplinarnih prilaza u okviru analize prijema medijskih i umetničkih sadržaja. Monodisciplinarni prilazi su povezani sa klasičnom osnovom humanističkih i društvenih nauka koje su povezane sa defincijom kulture zasnovanom na suprotnosti masovne i elitne kulture (umetnosti). Avant-gardni i lingvistički preokret u okvru društvenih nauka šezdesetih je realizovao ponovno prosuđivanje vrednosti pojma kulture - kultura se više ne posmatra kao zbir elitnih proizvoda ljudskog duha već pre kao proizvodnja kulturnih značenja, tj. kao diskurs. Ovaj preokret je omogućio međudsiplinarni preokret u okviru nauka kao što je estetika i istorija umetnosti $\mathrm{i}$ isto tako omogućio pojavu savremene, međudisciplinarne teorije medija.

KLJUČNE REČI: MONODSCIPLINARNOST, MEĐUDISCIPLINARNOST, MODERNIZAM, POSTMODERNIZAM, TEORIJA UMETNOSTI, ESTETIKA, ISTORIJA UMETNOSTI, AVANT-GARDA, TERIJA MEDIJA, PROUČAVANJA KULTURE

TRI SEKVENCE PISANJA-LOKACIJE

\section{Angela Harutyunyan}

Ovaj članak obuhvata tri vežbe/zadatka „pisanja lokacije“ prekinuta teoretskim i metodološkim pauzama. Ove sekvence odvode čitaoca u topografska i eksegetička putovanja u razne slike, tragove memorije i priče koji tretiraju 